\title{
Andean berries from Ecuador: A review on Botany, Agronomy, Chemistry and Health Potential
}

\author{
E. Carrillo-Perdomo ${ }^{\mathrm{a}}$, A. Aller ${ }^{\mathrm{a}}$, S.M. Cruz-Quintana ${ }^{\mathrm{b}}$, F. Giampieric $^{\mathrm{c}}$ and J.M. Alvarez-Suarez ${ }^{\mathrm{b}, *}$ \\ a Agroindustrial Engineering, Universidad Nacional de Chimborazo (UNACH), Campus Norte "Ms. Edison Riera \\ R." Riobamba, Chimborazo, Ecuador \\ ${ }^{\mathrm{b}}$ Facultad de Ciencias de la Salud. Universidad Nacional de Chimborazo (UNACH), Campus Norte "Ms. Edison \\ Riera R.”, Riobamba, Chimborazo, Ecuador \\ ${ }^{\mathrm{c}}$ Dipartimento di Scienze Agrarie, Universita Politecnica delle Marche, Ancona, Italy
}

Submitted 30 January 2015; accepted 15 March 2015

\begin{abstract}
Interest in exploring new and exotic types of berries has grown in recent years. Highly valued for its unique flavor, texture and color, recent researches have shown that Andean berries are an important source of bioactive compounds. This article provides botanical and agronomic descriptions and reviews the chemical and biological activities of two types of berries (Physalis peruviana L. and Solanum betaceum C.) and one commonly known as a berry, Rubus glaucus B. All highly consumed in Ecuador and enjoying great popularity in Andean traditional medicine. Although both traditional folk medicine and composition of these berries suggest significant health benefits, few studies to date have investigated these potentials.
\end{abstract}

Keywords: Rubus glaucus B., Physalis peruviana L. and Solanum betaceum C., Andean berries, anthocyanins, antioxidant properties, Health benefits.

\section{Introduction}

Eighty percent of the world population, especially in developing countries, uses plants as natural remedies and traditional medicine for facing primary needs of medical assistance [1], so Ecuador is not an exception. Ecuadorians have a sanitary system without a proper level of development that prevents a great part of the population from having access to formal medical care [2]. Nevertheless, since ancient times plants have played a relevant role in the development of Andean cultures, which is enhanced due to the high botanical diversity found in the Andes, including their use as therapeutic agents [3]. It is noteworthy that the country is one of the seventeen-megadiverse countries in the world [4, 5], being part of two biodiversity hotspots (Tumbes-Chocó-Magdalena and Tropical Andes) in only $283.560 \mathrm{~km}^{2}[6,7]$. Its richness includes ecological zones of great value, from mangroves to tropical forest, rainforest, moors and snow-capped mountains. Thus, one third of all Ecuadorian plant species have been used by people [8] and nowadays the use of medicinal plants is still an important feature of traditional medicine, which is daily practiced in many indigenous communities (30\% of the whole population belongs to different indigenous groups) and urban populations of all social classes $[9,10]$.

*Corresponding author: Dr. José M. Alvarez-Suarez, MSc, Ph.D, Facultad de Ciencias de la Salud. Universidad Nacional de Chimborazo (UNACH), Campus Norte "Ms. Edison Riera R." Avda. Antonio José de Sucre, Km. 1 1/2 Vía a Guano, Riobamba, Chimborazo, Ecuador. Tel.: +593 33730880; E-mail: malvarez@unach.edu.ec. 
Berries and their derived products have been shown to be exceptional functional products since they provide significant health benefits on several chronic conditions, including obesity, cancer, cardiovascular and neurodegenerative diseases because of their high content in phytochemicals, vitamins, minerals and fibre and the interactive synergies among their phytochemical components [11-14]. Recently, South American berries have been object of an increased interest mainly due to their potential health benefits and to the growing consumer interest in novel exotic fruits, particularly by international markets $[12,15]$. Nevertheless, while health-related properties and chemical composition of berries commonly found in North America and Europe have been widely explored; those natives from South America need more information. Several scientific reports have pointed out the therapeutic potential of certain plants and foods from this area, for instance Rubus glaucus B., Physalis peruviana L. and Solanum betaceum C. are among the relevant ones [16-23].

The development of functional products derived from berry fruits represents another alternative for the exploitation of Ecuadorian resources, to supplement their nutritional value and to promote new export channels. This review presents current knowledge on chemistry, composition, and health benefits of two berries ( $P$. peruviana L. and $S$. betaceum C.) and one commonly known as a berry, Rubus glaucus B.; which are mainly consumed in the Andean region of Ecuador.

\section{Rubus glaucus Benth}

\subsection{Botanical aspects}

R. glaucus is an evergreen shrub climber of the family Rosaceae and the genus Rubus, commonly called mora andina, mora de castilla or Andean blackberry in English-speaking countries. It is native to the northern part of the Andes, specifically the highland intertropical region, but it has also been introduced into many other tropical areas [21]. It is associated with blackberries of the subgenus Rubus and raspberries of the subgenus Idaeobatus as it shares morphological characters with both. Therefore, it is considered that $R$. glaucus is a fertile amphidiploid $(2 \mathrm{n}=21-84)$ product of hybridization between species of these two subgenera [24, 25]. It is a facultative apomictic species that produces sexual and asexual seeds (meiosis), so that sexual reproduction can occur in $10 \%$ of the population, thus maintaining genetic variability [26]. In Ecuador, the genetic variability of the species is poor and there are two wellformed groups [26]. Notably, the interesting gene pool of Andean blackberries has tried to be exploited for some years; thus, in the United States the Department of Agriculture (USDA) and other institutions have used $R$. glaucus germplasm to improve the characteristics of blackberries: fruit size, fruit quality, disease resistance and adaptation to climatic conditions of the southern United States [27].

The plant is a perennial bush-vine that reaches up to 2 meters tall and 3 meters long, whose trunk divides into several branches (5-10 or more) which are the stems [28]. The stems are cylindrical, long, erect, without villi, light green, red or dark brown and with prickly spines curved gradually tapering from base to tip [28, 29]. Sometimes the stems are covered by a kind of blue-white powder. The leaf consists of three lanceolate subcoriaceous leaflets rounded or slightly truncated at the base with acuminate apex and biserrate margin. The lower face of the leaves is whitish and villi. The inflorescences are lax and condensed, with 15 to 22 flowers and thorny pedicels without villi. The flowers are 18 to $22 \mathrm{~mm}$ in diameter, deltate sepals and ovate white petals. Although Andean blackberry is commonly referred as a berry; botanically do not correspond to this type of fruit. It is an aggregate fruit (seeds from different ovaries of a single flower) composed of many drupelets and has a size of about 1 to $2.5 \mathrm{~cm}$ long. It is from hairy to glabrous, red or black, from ovoid to rounded, with recurved sepals and with 70 to 100 drupeolas per well [28]. They are dark-red or purple when ripe and have a unique, heady, pleasant aroma and bittersweet flavor (Fig. 1A) [21].

\subsection{Agronomic aspects}

The Andean blackberries are produced from Mexico to Ecuador, being widely cultivated in Colombia, Costa-Rica and Ecuador where they grow all year round [30-32]. This is the only native species of Rubus grown commercially in the countries of Central and South America, where it is prized for its attractive dark-red color (Fig. 1A), juiciness 
A)

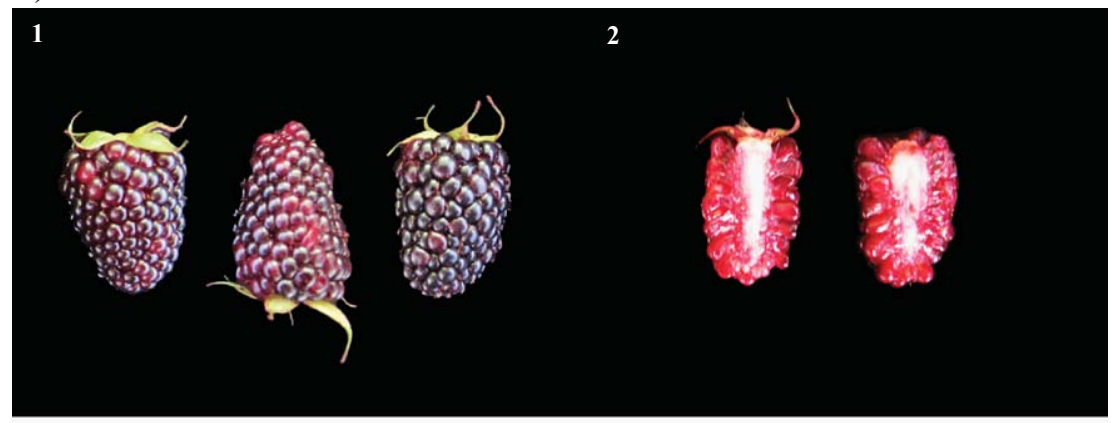

B)

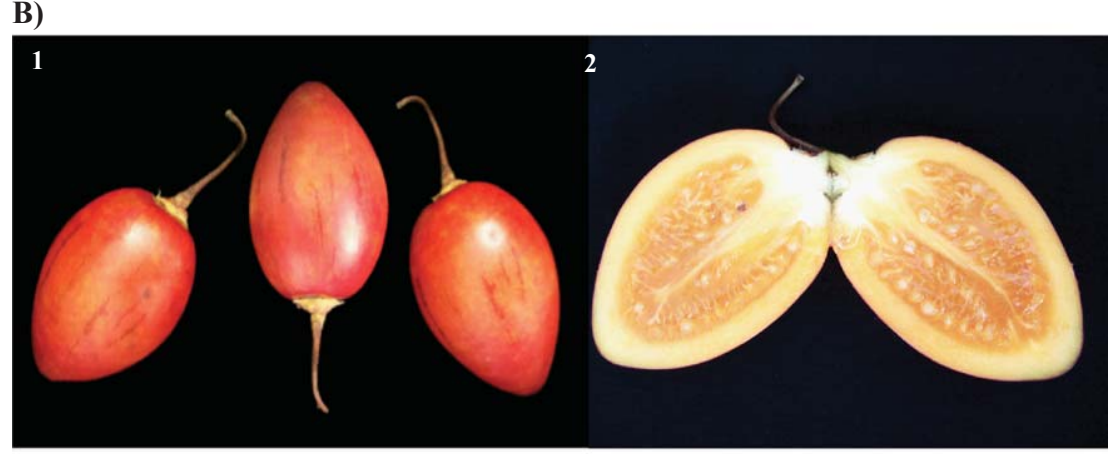

C)

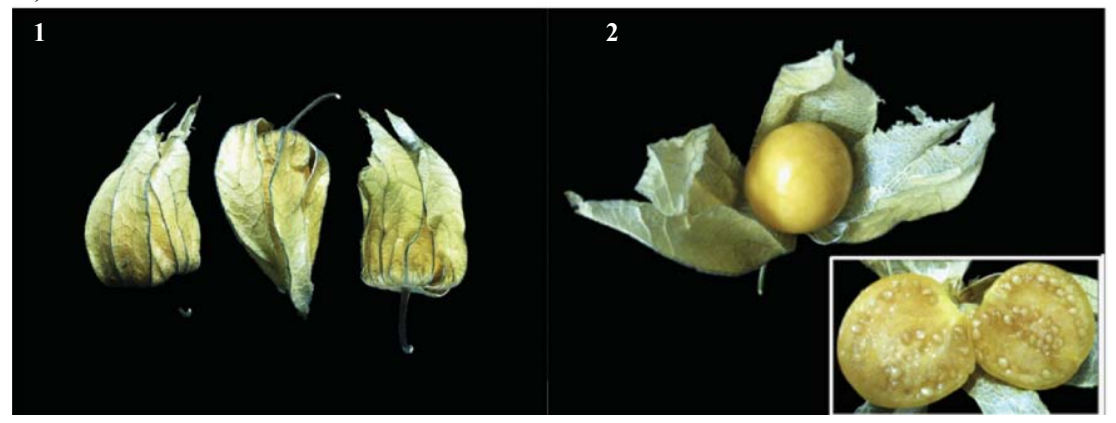

Fig. 1. Whole (1) and halved (2) Rubus glaucus (A), Solanum betaceum (B) and Physalis peruviana (C) fruits.

and flavour compared to other most popular blackberries [12]. In Ecuador, the Andean blackberry grows in the wild in isolation, scattered or in groups with other species [33] finding as optimal areas for production the Inter Andean valleys, mainly in the provinces of Tungurahua and Pichincha. Nonetheless, it has become an important production for the provinces of Carchi and Imbabura. There are 4 varieties commonly planted: "Castilla", "Brazo", "Gato" and "Criolla" [34]. R. glaucus is the Rubus species of major commercial importance and greater acceptance among farmers, industry and consumers in Ecuador; so that, $98 \%$ of cultivated blackberries are Andean blackberries, which are consumed fresh or processed into products such as frozen pulp, juice, jam, or wine [33, 35]. Moreover, $R$. glaucus fruits are a promising source of natural colorants (anthocyanins) [36].

$R$. glaucus has a wide altitudinal adaptation, growing between 1.500 to $3.200 \mathrm{~m}$. However, it achieves optimal development between 2.500 to $3.100 \mathrm{~m}$ in moderately cold climates with temperatures around 12 to $18^{\circ} \mathrm{C}$, high relative humidity (80-90\%), high luminescence and an annual rainfall of 500 to $10000 \mathrm{~mm}$ well distributed. The Andean blackberry is susceptible to frosts, so it is important to know the microclimate before implementing the 
crop. It grows best in sandy loam soils high in organic matter, phosphorous and potassium; and well-drained soils, since plants are highly susceptible to flooding. The plants have a good adaptation to slightly acidic soils with a pH of 5.5 to 7.5, with an optimal of 7. However, they are susceptible to drought, so it is important to have a water source. The yield is also reduced due to the incidence of several diseases and pests, among which the most important are aphids, mites, spider mites, beetles, mildew, powdery mildew, verticillium wilt or grey mold [37]. Ecuador has about 46.100 hectares with high potential for crop sowing, located mainly in the provinces of Pichincha, Tungurahua, Chimborazo, Carchi and Imbabura (Fig. 2A). However, the highest yield registered in the country so far has been about 5 tons/hectare between 2001 and 2006 [34]. The first harvest of $R$. glaucus berries starts between 10 and 12 months after transplantation; then weekly harvests are performed continuously, with some periods of production concentration [38]. The production increases over time and stabilizes at 18 months, finding that the timely production of plants could be 10-15 years, depending on their management [37]. These berries are highly perishable during postharvest handling and about $30 \%$ of the harvested product is discarded due to difficulties in postharvest conservation, which results in a short lifespan (approximately 10 days) [31].

\subsection{Nutrients}

According to its nutrient profile (Table 1) Andean blackberry is low in total calories, with a $100 \mathrm{~g}$ serving providing only $43 \mathrm{kcal}$ [39]. Their high fiber content $(5.3 \mathrm{~g} / 100 \mathrm{~g}$ of fruit) can contribute to control calorie intake by its satiating effect, and coupled with the fructose content ( $>50 \%$ of total sugars) may regulate blood sugar levels by slowing digestion. The fat contained in the oil of blackberry seeds is formed approximately by $82.11 \%$ of unsaturated fatty acids, being a source of healthy essential fats. The fat-soluble vitamins as vitamin $\mathrm{K}$ and tocopherols have also been identified in the seeds, while most interest has focused on the high levels of the water-soluble vitamin $\mathrm{C}$ present in the flesh, which can reach $21 \mathrm{mg} / 100 \mathrm{~g}$ of fresh weight $(\mathrm{FW})$. Besides vitamin $\mathrm{C}$, the folate content in blackberry is another feature that allows to highlight that, among fruits, blackberry is one of the richest natural sources of this essential micronutrient with a content $\sim 25 \mu \mathrm{g} / 100 \mathrm{~g}$ FW. Moreover, the Andean blackberry, although to a lesser extent, is a source of other vitamins such as thiamin, riboflavin, niacin, vitamin B6 and vitamin A, as well as several minerals such as calcium, magnesium, phosphorus and potassium [39].

\subsection{Phytochemistry}

Andean blackberry is a natural source of polyphenols mainly represented by the extensive class of phenolic compounds that have been associated with significant beneficial effects on human health [40]. The major class of phenolic compounds is represented by the flavonoids (anthocyanins, flavonols, flavanols), followed by hydrolyzable tannins (gallic and ellagic acid derivatives) and phenolic acids (mainly hydroxycinnamic acids) (Table 2).

Anthocyanins (ACYs) are the phenolic compounds responsible for the red to purple to black pigments of fruits and vegetables [40]. Although there are few studies, some investigations have quantified the total anthocyanin content in Andean blackberry, reporting values of about $45 \mathrm{mg} / 100 \mathrm{~g} \mathrm{FW}$ [23]. Approximately 10 different ACYs pigments have been described, with cyanidin-derivatives as the most predominant, while pelargonidin-derivatives are frequently identified, although only in smaller proportions [31, 40-43] (Table 2). Glucose seems to be the most common substituting sugar in Andean blackberry ACYs, although others substituents as rutinose, sambucus, and xylosylrutinoside moieties have been also identified attached at the C3 position of the flavin structure [40].

Because of their important impact on human health, ellagitannins (ETs) represent another important group of phytochemicals to consider in Andean blackberry. ETs consist of different combinations of gallic acid and hexahydroxydiphenic acid with glucose, forming a group of structures such as monomers (ellagic acid [EA] glycosides), oligomers (sanguiin H-6 and Lambertianin C), and complex polymers. Although ETs have often been identified as the active principals in medicinal plants [23,43], the ETs content and composition in blackberry have been characterized only recently. The total contents of ETs in Andean blackberry have been estimated approximately of $3547 \mathrm{mg}$ of ellagic acid equivalent/kg of fresh weight (FW) [43], with Lambertianin C and Sanguiin H-6 as the most representative (Table 2), and as a basic unit of many ETs. Moreover, ellagic acid as well as gallic and ellagic acid (EA) derivatives have been also identified. 
A)

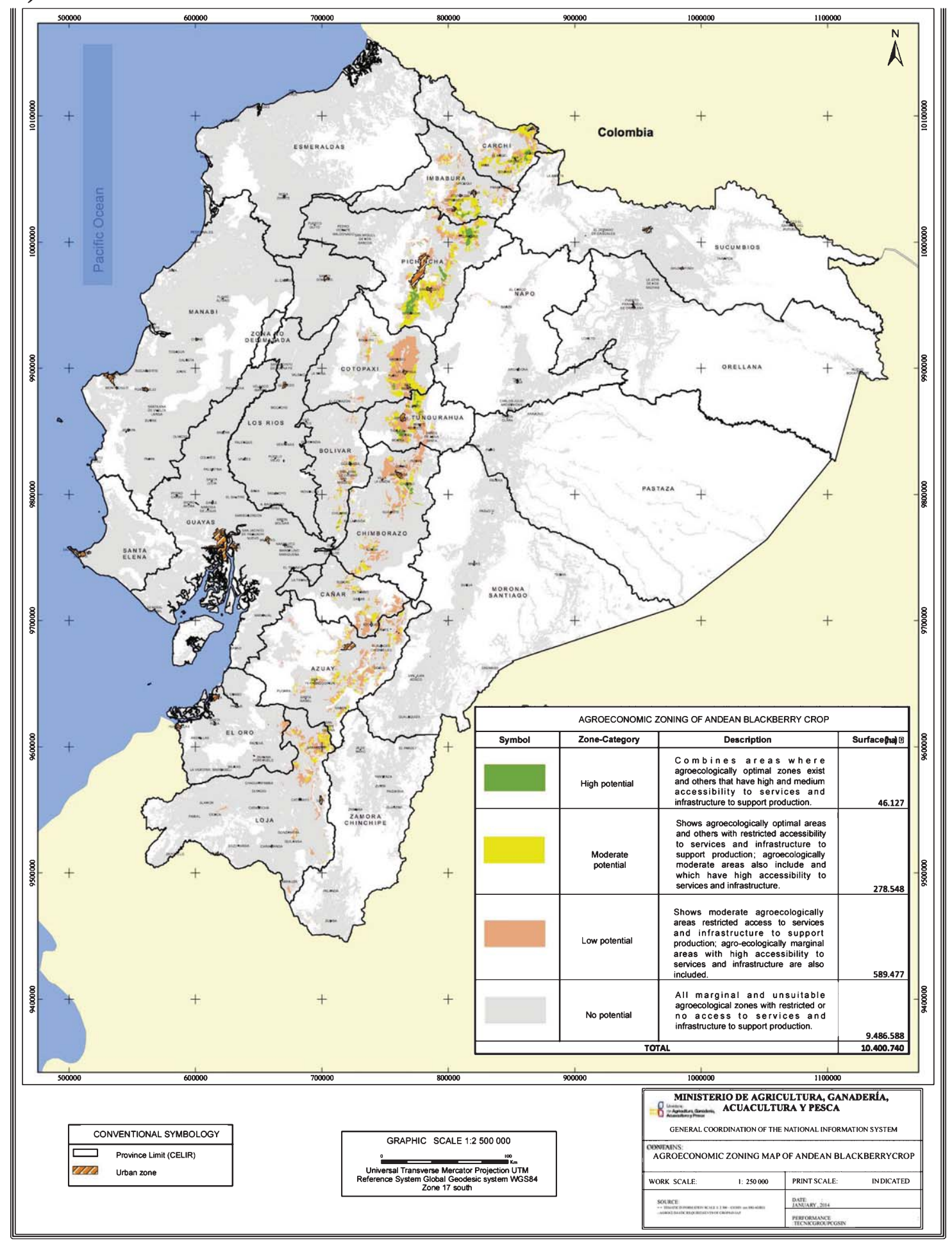

Fig. 2. (Continued) 
B)

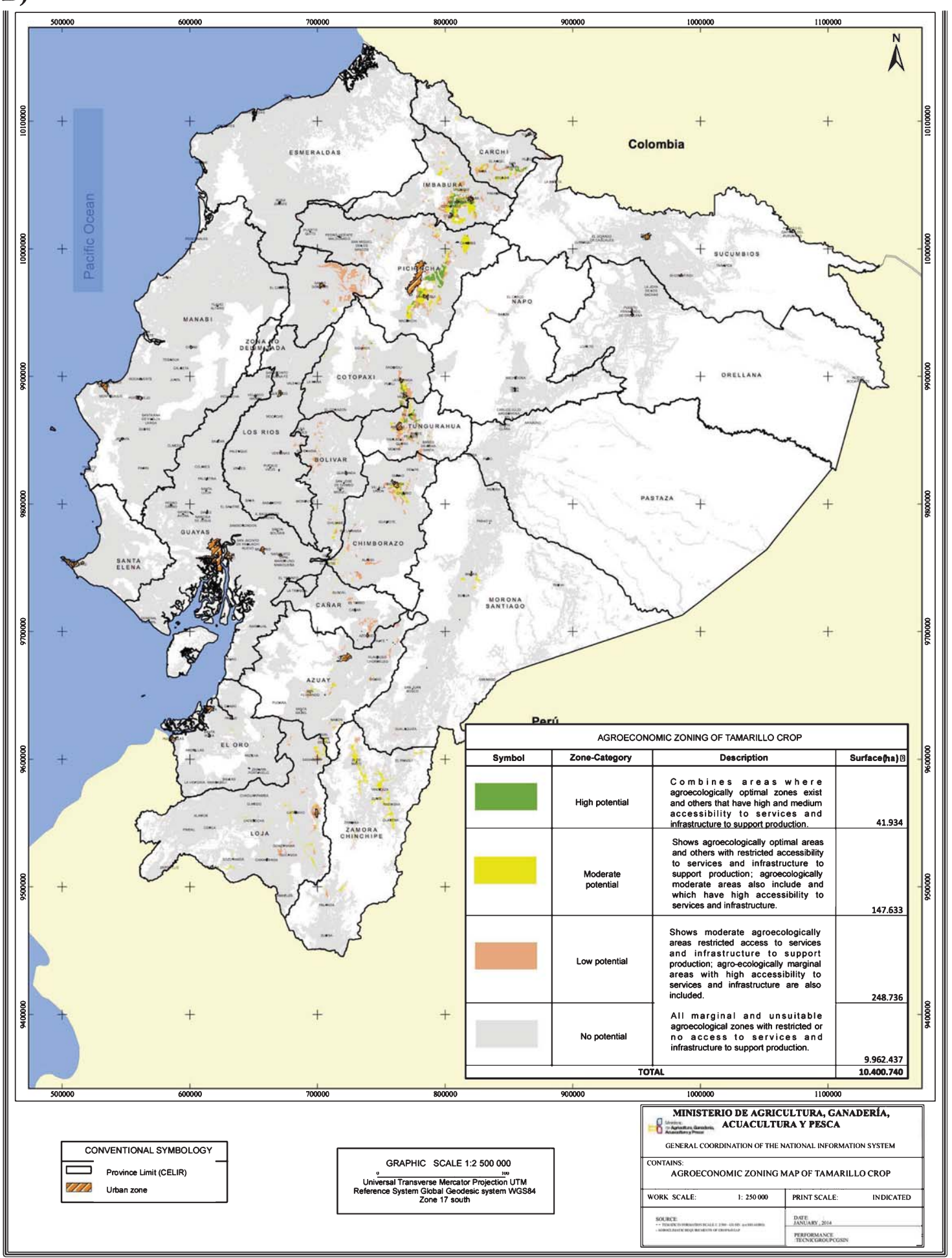

Fig. 2. (Continued) 
C)

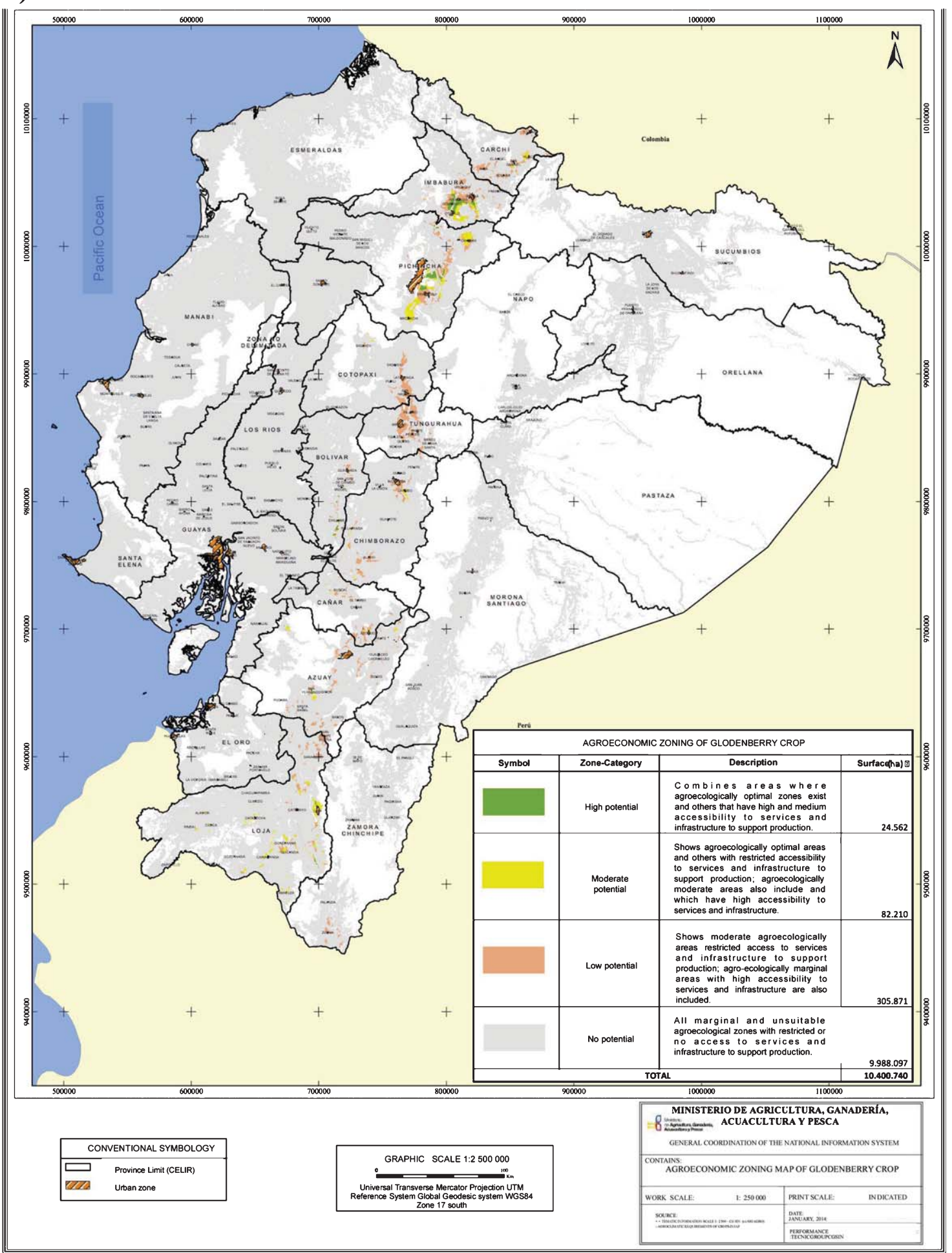

Fig. 2. Agroeconomic zoning maps of Andean blackberry (A), tamarillo (B) and goldenberry (C) crops throughout Ecuador modified from Bucheli et al. (2014) [34, 63, 89]. 
Table 1

Nutrient composition of fresh Andean blackberry (R. glaucus Benth.) [28]

\begin{tabular}{|c|c|c|}
\hline Type & Nutrient & per $100 \mathrm{~g}$ \\
\hline \multirow[t]{10}{*}{ proximates } & water (g) & 88.15 \\
\hline & energy (kcal) & 43 \\
\hline & protein $(\mathrm{g})$ & 1.39 \\
\hline & carbohydrates & 9.61 \\
\hline & total lipid (g) & 0.49 \\
\hline & dietary fiber (g) & 5.3 \\
\hline & sugars (g) & 4.88 \\
\hline & sucrose $(\mathrm{g})$ & 0.07 \\
\hline & glucose (g) & 2.31 \\
\hline & fructose $(\mathrm{g})$ & 2.40 \\
\hline \multirow[t]{9}{*}{ minerals } & calcium (mg) & 29 \\
\hline & iron (mg) & 0.62 \\
\hline & magnesium (mg) & 20 \\
\hline & phosphorus (mg) & 22 \\
\hline & potassium (mg) & 162 \\
\hline & sodium (mg) & 1 \\
\hline & zinc $(\mathrm{mg})$ & 0.53 \\
\hline & copper (mg) & 0.17 \\
\hline & manganese (mg) & 0.65 \\
\hline \multirow[t]{11}{*}{ vitamins } & Vitamin C (mg) & 21.0 \\
\hline & Thiamin (mg) & 0.02 \\
\hline & Riboflavin (mg) & 0.02 \\
\hline & Niacin (mg) & 0.64 \\
\hline & Vitamin B-6 (mg) & 0.03 \\
\hline & Folate $(\mu \mathrm{g})$ & 25.0 \\
\hline & $\alpha$-tocopherol (mg) & 1.17 \\
\hline & $\beta$-tocopherol (mg) & 0.04 \\
\hline & $\gamma$-tocopherol (mg) & 1.34 \\
\hline & $\Delta$-tocopherol (mg) & 0.90 \\
\hline & vitamin $K(\mu g)$ & 19.8 \\
\hline \multirow[t]{3}{*}{ Lipids } & Saturated (g) & 0.01 \\
\hline & Monounsaturated (g) & 0.04 \\
\hline & Polyunsaturated (g) & 0.28 \\
\hline
\end{tabular}

Andean blackberry also contains small amounts of other phenolic compounds. The content and composition of flavonols have been reported [43], being mostly identified as derivatives of quercetin and kaempferol, with quercetin derivatives as the most abundants. Flavanols are the only class of flavonoids that do not occur naturally as glycosides. These compounds have been identified in Andean blackberry in monomeric form such as epicatechin and flavanol derivative. Finally, phenolic acids in Andean blackberry are mainly hydroxycinnamic acids (caffeic, $m$-coumaric, $p$-coumaric, and ferulic acid) [23], which have been identified as minor constituents.

\subsection{Biological activities and health effects}

R. glaucus fruits play an important role in Andean culture because of their use in health and nutrition. In general, berries have been long studied for their biological activity, having been focused fundamentally on species produced 
Table 2

Polyphenolic composition reported in Andean blackberry (R. glaucus Benth) [28]

\begin{tabular}{|c|c|c|c|}
\hline Class & Goup & Compound & Ref. \\
\hline \multirow[t]{3}{*}{ Phenolic acids } & Hydroxycinnamic acids & Caffeic acid & 23 \\
\hline & & Coumaric acid & 23 \\
\hline & & Ferulic acid derivatives & 23 \\
\hline \multirow[t]{15}{*}{ Flavonoids } & Flavanols & Epicatechin & 43 \\
\hline & & Flavanol derivative & 43 \\
\hline & Flavonols & Quercetin-glycosides & 43 \\
\hline & & Quercetin-3-glucuronide & 43 \\
\hline & & Quercetin-3-arabinoside & 43 \\
\hline & & Kaempferol-3-glucuronide & 43 \\
\hline & Anthocyanins & Cyanidin-glycoside & 43 \\
\hline & & Cyanidin-3-glucoside & 23 \\
\hline & & Cyanidin-3-rutinoside & 23 \\
\hline & & Cyanidin-3-sambubioside & 42,31 \\
\hline & & Cyanidin-3-glucoside & 42,31 \\
\hline & & Cyanidin-3-xylosylrutinoside & 42,31 \\
\hline & & Cyanidin-3-rutinoside & 42,31 \\
\hline & & Pelargonidin-3-glucoside & 42,31 \\
\hline & & Pelargonidin-3-rutinoside & 42,31 \\
\hline \multirow[t]{7}{*}{ Hydrolyzable tannins } & Ellagitannins & Gallic acid & 23 \\
\hline & & Gallic acid derivatives & 23 \\
\hline & & Ellagic acid & 43 \\
\hline & & Ellagic acid derivatives & 43 \\
\hline & & 2 ellagitannins & 43 \\
\hline & & Lambertianin $\mathrm{C}$ & 43 \\
\hline & & Sanguiin H-6 & 43 \\
\hline
\end{tabular}

in the United States and Europe. Thus, despite the effects of Andean berries in human health they have been poorly studied.

The consumption of Andean blackberry in Ecuador is widespread, which is further favored due to its availability almost all year. This allows a large consumption mainly as fresh fruit or juices, and to a lesser extent as processed forms such as jams and jellies. The fact that most fruits are consumed in natural forms without the intervention of industrial processes allows the preservation of their phytochemicals and therefore its nutritional and health properties.

According to the Ecuadorian Andean popular culture, consumption of R. glaucus satisfies hunger and helps digestion, makes stronger the body against disease and enhances the senses [44]. These healthy properties could be explained in a simple way if it is considered that Andean blackberry can favor intestinal transit due to the high presence of fibers and phytochemical content such as vitamin $\mathrm{C}$ and ACYs that serve as antioxidants. The amount of potassium that contains helps the generation and transmission of nerve impulses, as well as people with strong muscle activities. Although there is no concrete scientific evidence of the health effects of Andean blackberry, several studies in other varieties of blackberries can justify the beneficial effect of consuming this kind of fruit.

An example would be if the ACYs content in the fruit is considered. ACYs are reported to exert an important antioxidant capacity, as well as anti-inflammatory, antiviral, antiproliferative and anti-carcinogenic properties [45]. Moreover, currently there is special interest in the health benefits of the ETs of these fruits. Health benefits of particular blackberry ETs and EA have not been explored so far, although recent studies of ETs and EA detailed the anti-inflammatory, antimicrobial, prebiotic, antioxidant, estrogenic and/or antiestrogenic effect of dietary ETs and EA [40]. 


\subsubsection{Antioxidant capacity $(A C)$}

When referring to the biological properties of berries, the first aspect that is highlighted is its high AC. The AC of blackberry was one of the first aspects to be studied and for a long time was taken as the main justification for its beneficial effects on health. At present, it is known that its health effects are not only linked to these biological properties, which are beyond the antioxidant properties. Despite this, the AC of berries cannot be put aside, whereof the main responsibilities are the vit $\mathrm{C}$ and ACYs.

Living organisms present a reduction-oxidation system that is necessary to maintain a balance between free radicals generated and the antioxidant system. The formation of large amounts of free radicals may cause oxidative stress (OS), accelerating the aging and causing many of the principal degenerative diseases that are currently affecting humanity [46]. One of the ways through which the harmful effects of oxidative stress can be prevented and counteracted is the daily consumption of natural antioxidants. The most significant results in the berries intervention studies in healthy humans have been the significant increases in the AC of plasma after an acute [47-49] or a protracted [50] strawberries intake. In terms of $\mathrm{AC}$, one study ranked the $\mathrm{AC}$ of blackberries third highest after strawberry and black raspberry on the basis of their ORAC results [51]. These results can be attributed to the high amounts of acylated ACYs in blackberry. ACYs act by scavenging free radicals, with a 3, 4-dihydroxy substituent in the B ring being a key criterion for radical scavenging. They react readily with radicals such as hydroxyl ( $\mathrm{OH})$, azide (N3), and peroxyl (ROO') to form stable flavonoid radicals, and thus reducing OS [52]. Moreover, ACYs also act protecting fatty acids from oxidation and enhance fatty acid stability by reacting with $\alpha$-tocopherol radicals to form $\alpha$-tocopherol. The antioxidant function of ACYs is also evidenced by its capacity to chelating metal ions at moderate $\mathrm{pH}$ levels with their ionized hydroxyl groups of the B ring [52].

\subsubsection{Health benefits}

At present, cardiovascular diseases (CVD) have been classified as the world's "biggest killers" and are considered one of the major causes of mortality among non-transmittable diseases [53]. Numerous scientific evidences support the hypothesis that consumption of berries can positively affect the risk factors involved in CVD. Therefore, the effects of berries in the prevention of CVD have been demonstrated by their capacity to inhibit inflammation and platelet aggregation; improve endothelial function, plasma lipid profile and free radical scavenging; or increase lowdensity lipoprotein (LDL) resistance to oxidation [54]. The consumption of Andean blackberry could affect pathways related to cardiovascular health by several different mechanisms. The ability to protect against oxidation could be considered an appropriate mechanism related with the phytochemical composition of Andean blackberry. In fact, Andean blackberry is a rich source of some of the most potent dietary antioxidants in vitro, such as vitamin C, ACYs and ETs [31, 40-43].

Elevated levels of LDL in plasma are considered a risk factor for CVD [55]. The high contents of cyanidin glycosides in blackberries have been associated with its $\mathrm{AC}$ and its ability to protect against LDL oxidation, whereas the hydroxycinnamic acids are most important in the liposome oxidation system. Phenolic compounds from berries have shown protective effects against CVD by their capacity to inhibit the oxidation of LDL by quenching free radicals through donation of hydrogen molecules $[55,56]$. It has also been demonstrated that berries phenolics protect LDL from hydrogen peroxide-induced oxidation in human endothelial cells in vitro [57]. In vitro studies have demonstrated that ACYs are able to protect human primary endothelial cells by suppressing the secretion of cytokine-induced chemokine monocyte chemotactic protein 1 (MCP-1), a protein directly involved in atherogenesis through its chemotactic function to sites of infection or inflammation [58]. Recently it has also been shown that consumption of berries, specifically strawberries, significantly decreased the number of activated platelets, compared to baseline, which is a critical factor in the pathogenesis of CVD [59]. Moreover, in vitro studies have shown that berries flavonoids are able to reduce platelet aggregation and increase platelet nitric oxide production [60].

Besides CVD, cancer is classified as the second cause of death in developed countries. Cancer is a complex process that begins with a cancer cell caused by DNA damage, which continues with accumulation of mutations, promotion of cell proliferation and tumor expansion, and finally progression to malignancy and metastasis [61]. Many studies have demonstrated the potential cancer chemopreventive activities of berries [61]. The phytochemicals present in berries may modulate initiation, promotion, and progression of cancer [62]. The possible anticarcinogenic mechanisms include antioxidant activity, stimulation of antioxidant enzymes; inhibition of carcinogen-induced DNA adducts formation and enhancement of DNA repair [57]. Although antioxidation plays a crucial role in the 
anticancer capacity of berries, recent studies have exposed the role of berries phytochemicals in modulating cellular processes associated with cancer progression, such as detoxification activity, induction of apoptosis, antiproliferative, and antiangiogenic activity, many of which have been attributed to ACYs. It has been also shown that ACYs are able to induce phase II enzymes, and therefore, inhibiting possible DNA damage caused by carcinogens [57].

The results here exposed, allow the conclusion that Andean blackberry is an important source of natural antioxidants with potential health effects and that specific blackberry components may be involved in different chemical and molecular pathways in exerting their antioxidant and anticarcinogenic effects and in preventing CVD, thus stressing the need for further investigations.

\section{Solanum betaceum $\mathrm{C}$}

\subsection{Botanical aspects}

The species is indigenous to the Andean region of Bolivia, Chile, Ecuador, Argentina and Peru, where it has been given different common names such as tamarillo, limatomate, tomate de monte, tomate de árbol, tomate de la paz or tree tomato in English-speaking countries [20]. S. betaceum is a small pubescent tree that reaches from 2 to $5 \mathrm{~m}$ in height and rarely $7 \mathrm{~m}$. It has a single, short, monopodial and grey trunk branched into 2 or 3 branches. The alternate, simple and entire leaves are usually grouped at the tips of the branches with a robust petiole and the lamina is ovate, subcarnose, shortly acuminate with cordate base and slightly pubescent on the underside. The flowers are fleshy, pink, hermaphrodites, pentamerous, fragrant and pedicellates and gather in groups of 3 to 10 in axillary cymes or racemes near the ends of the branches. The fruits are ellipsoidal or ovoid, obtuse or acute at apex, with lengths from 4 to $10 \mathrm{~cm}$ and wide of 3 to $5 \mathrm{~cm}$, glabrous, yellow to orange, red, or purple, often with darker longitudinal marks. The color of the fruit once ripe depends on the variety. Inside the fruits, the mesocarp is orange, fleshy and contains numerous small, round, flat and hard seeds (Fig. 1B) [20].

\subsection{Agronomic aspects}

In addition to the aforementioned countries, Andean blackberry is cultivated in Argentina, Australia, Brazil, Colombia, Indonesia, Kenya, Malaysia, Papua New Guinea, Philippines, Thailand, United States, Venezuela, Vietnam and New Zealand [20]; and it is used to be consumed fresh, seasoned, in salads, juices, smoothies, sorbets, alcoholic drinks, puree, sauces, cooked dishes, desserts or jams. In Ecuador, 54\% of total provinces (Azuay, Bolívar, Carchi, Chimborazo, Cotopaxi, Imbabura, Morona Santiago, Napo, Loja, Pichincha, Sucumbíos, Tungurahua and Zamora Chinchipe) are producers and in 2013 the area planted was almost 6.000 hectares (Fig. 2B) [63]. The country currently produces three different varieties: the "common tamarillo" (elongated, purple and orange), the "round tamarillo" (reddish orange) and the "blackberry tamarillo" (oblong and purple). However, the expansion of this crop is limited by factors such as the lack of clear differentiation among varieties, low fruit quality (heterogeneity and phytosanitary problems), the use of inappropriate varieties or replacement of local varieties by materials from other origins not adapted [64]. Some works studying genetic diversity have indicated the existence of considerable variability and that it is possible to select materials with characteristics more suitable for fruit market $[19,64-66]$; however, more investigations related to its conservation and genetic improvement are needed [64, 67].

The tamarillo is a subtropical tree able to bloom from altitudes of 1.000 to $3.000 \mathrm{~m}$ in the tropics and subtropics; however, in the coldest areas of the subtropics it may develop from 300 to $1.000 \mathrm{~m}$. Despite being tolerant to low temperatures above $10^{\circ} \mathrm{C},-2^{\circ} \mathrm{C}$ temperatures can cause important damages to young foliage, juvenile branches and seedlings. The optimum temperature for its growth of is around 18 to $22^{\circ} \mathrm{C}$ and requires annual precipitation of 600 to $800 \mathrm{~mm}$. Cool temperatures promote flowering, while high temperatures affect both bloom and fruiting, as prolonged droughts do. The tree is susceptible to strong winds as it has fragile branches, weak foliage and superficial roots, which also prevents sowing in heavy clays and compacted or waterlogged soils. Therefore, plants grow best in well-drained, friable and light soils [20]. The yield is also reduced due to the incidence of diseases such as anthracnose, powdery mildew, some viruses and nematodes [68]. Thus, the average yield in Ecuador during 2012 was about 7 tons/hectare. Nevertheless, the country has about 41.900 hectares with high potential 
Table 3

Nutrient composition of fresh tree tomato (Solanum betaceum C.) [20]

\begin{tabular}{|c|c|c|}
\hline Type & Nutrient & per $100 \mathrm{~g}$ \\
\hline \multirow[t]{10}{*}{ proximates } & water (g) & 87.8 \\
\hline & energy (kcal) & 31 \\
\hline & protein $(\mathrm{g})$ & 1.5 \\
\hline & carbohydrates & 10.3 \\
\hline & total lipid (g) & 1.28 \\
\hline & dietary fiber (g) & 4.2 \\
\hline & sugars $(\mathrm{g})$ & 4.7 \\
\hline & sucrose $(\mathrm{g})$ & 2.5 \\
\hline & glucose (g) & 1.0 \\
\hline & fructose (g) & 1.2 \\
\hline \multirow[t]{9}{*}{ minerals } & calcium (mg) & 11.3 \\
\hline & iron $(\mathrm{mg})$ & 0.94 \\
\hline & magnesium (mg) & 22.3 \\
\hline & phosphorus (mg) & 13.1 \\
\hline & potassium (mg) & 349 \\
\hline & sodium (mg) & 8.9 \\
\hline & zinc (mg) & 0.20 \\
\hline & copper (mg) & 0.20 \\
\hline & manganese (mg) & 0.20 \\
\hline \multirow[t]{6}{*}{ vitamins } & vitamin C (mg) & 33.9 \\
\hline & vitamin A (I.U) & 2475 \\
\hline & carotene (mg) & 0.65 \\
\hline & thiamine (mg) & 0.13 \\
\hline & riboflavin (mg) & 0.048 \\
\hline & niacin $(\mathrm{mg})$ & 1.0 \\
\hline
\end{tabular}

for sowing crops, located mainly in the provinces of Tungurahua, Carchi, Chimborazo, Cotopaxi, Imbabura and Pichincha (Fig. 2B).

\subsection{Nutrients}

The consumption of products low in sodium, rich in dietary fiber, potassium and other minerals, vitamins and antioxidant phytochemicals, are characteristic of well-balanced diets. According to their nutritional profile (Table 3), tree tomato fruits are low in total calories $(31 \mathrm{kcal} / 100 \mathrm{~g})$ and sodium $(8.9 \mathrm{mg} / 100 \mathrm{~g})$, but rich in dietary fiber $(4.2 \mathrm{~g} / 100 \mathrm{~g})$, potassium $(349 \mathrm{mg} / 100 \mathrm{~g})$, as well as vitamins such as the water-soluble vitamin $\mathrm{C}(33.9 \mathrm{mg} / 100 \mathrm{~g})$ [20]. To these characteristics a group of ACYs and carotenoids with high antioxidant properties is added to be discussed below, that make the tree tomato an excellent choice as a source of dietary natural compounds beneficial to health.

\subsection{Phytochemistry}

The studies concerning the chemical composition of tree tomato are relatively recent [36]. At present, the tree tomato is a promising product for export, and due to its color, the red variety has been the most accepted internationally. The tree tomato fruits predominantly contain anthocyanins and carotenoids, while phenolic acid and other flavonoids have been identified as minor constituents [36]. Thus, it has been reported that the levels of anthocyanins and carotenoids 
Table 4

Phytochemical composition reported in tree tomato (Solanum betaceum C.) [22, 36, 69]

\begin{tabular}{|c|c|c|}
\hline Class & Goup & Compound \\
\hline Phenolic acids & Hydroxycinnamic acids & $\begin{array}{l}\text { Dicaffeoylquinic acid } \\
\text { Caffeoylquinic acid } \\
\text { Caffeoyl glucose } \\
\text { Feruloyl glucose }\end{array}$ \\
\hline Flavonoids & Anthocyanins & $\begin{array}{l}\text { Delphinidin glucosyl- rutinoside } \\
\text { Delphinidin rutinoside } \\
\text { Cyanidin rutinoside } \\
\text { Pelargonidin rutinoside } \\
\text { Delphinidin 3- } O \text {-(6"- } O \text { - } \alpha \text {-rhamnopyranosyl- } \\
\beta \text {-glucopyranosyl)-3'- } O \text { - } \beta \text {-glucopyranoside } \\
\text { Delphinidin 3- } O \text {-(6"- } O \text { - } \alpha \text {-rhamnopyranosyl)- } \beta \text {-glucopyranoside } \\
\text { Cyanidin 3-O-(6"-O- } \alpha \text {-rhamnopyranosyl)- } \beta \text {-glucopyranoside } \\
\text { Pelargonidin 3-O-(6"-O-arhamnopyranosyl)- } \beta \text {-glucopyranoside }\end{array}$ \\
\hline Carotenoids & $\begin{array}{l}\text { Carotenes } \\
\text { Xanthophylls }\end{array}$ & $\begin{array}{l}\beta \text {-carotene } \\
\text { Zeaxanthin } \\
\beta \text {-cryptoxanthin } \\
\text { Lutein }\end{array}$ \\
\hline
\end{tabular}

found in tree tomato fruits are approximately of $0.371-0.653 \mathrm{mg} / 100 \mathrm{~g}$, respectively [20]. About 8 different ACYs pigments have been described, with delphinidin and cyanidin derivatives as the most predominant forms and glucose and rhamnose, in pyranose form, as the most common substituents, while pelargonidin-derivatives have been identified but only in smaller proportions [36] (Table 4).

Besides the ACYs, carotenoids are another important group of compounds identified in tree tomato. Carotenoids are organic pigments that are found in the chloroplasts and chromoplasts of plants, characterized by abundant conjugated double bonds, which are responsible for the potent antioxidant properties of these compounds. The most abundant carotenoids identified in tree tomato belong to the xanthophylls, with zeaxanthin, $\beta$-cryptoxanthin and lutein as the most predominant, while $\beta$-Carotene, from the carotenes group, have been also reported [22]. For phenolic acids, hydroxycinnamic acids are the majors. Among them, dicaffeoylquinic acid, caffeoylquinic acid, caffeoyl glucose and feruloyl glucose [69] are the most predominant.

\subsection{Biological activities and health effects}

\subsubsection{Antioxidant capacity $(A C)$}

At present, the increasing interest in tree tomato as a potential new crop has led to several studies, mostly related to its chemical composition, while studies related to their biological properties are still scarce. Consumption of fresh fruit or as juice is widespread throughout Ecuador and Andean region. Using the traditional method of preparation of fruit juices in the Andean region, the researchers found that the best antioxidant activity derived from maceration, compared with jams and jellies [18], probably as a consequence of the conservation of some natural antioxidants that, in some cases, may be lost or may decrease their properties through industrial processes. Furthermore, the insoluble matters (pomace) obtained after preparing juice showed a higher antioxidant capacity compared to when it is obtained after the industrialization process [18].

Lipophilic compounds in tree tomato have also attracted interest from researchers. Within these, carotenoids are a group of great interest, especially for his significant AC [69]. The chemopreventive role of carotenoids as antioxidants, anticarcer and antimutagenic has been supported by many epidemiologic studies [70]. The ethyl acetate fraction from tree tomato has exhibited the highest DPPH scavenging activity and Trolox equivalent antioxidant capacity (TEAC) compared with aqueous and ethanolic fractions [69]. 
Finally, a recent study has shown that one protein with molecular mass around $17 \mathrm{kDa}$, purified from tree tomato, was able to inhibit uric acid formation and reduce oxidative damage by scavenging hydroxyl radicals and superoxide anion in a dose-dependent manner. This study showed that this protein might constitute a promising source for the production of bioactive peptides, as well as its potential use for the development of functional foods with a beneficial impact on human health [71].

\subsubsection{Health benefits}

The medical uses of tree tomato are mainly based in empirical knowledge of popular culture. The medicinal uses of tree tomato in Colombia and Ecuador are related to sore throats and flu. The fruit or leaves, previously heated, are applied topically against inflammation of tonsils. For influenza, fruits should be eaten fresh. In Venezuela is used to raise hemoglobin in the treatment of anemia.

Yellow varieties are a good source of carotenes, and xanthins, compounds that possess antioxidant properties and, together with vitamin A, are essential for visual health. Further, vitamin A is also required for maintaining healthy mucus membranes and skin. The fruits are also a very good source of electrolyte, such as potassium, that is an important component of cell and body fluids helping to control heart rate and blood pressure, counteracting the negative action of sodium. Tree tomato in Andean culture has been traditionally used to reduce blood cholesterol levels and to treat respiratory problems. The pulp is also used for the prevention of neurodegenerative diseases and arteriosclerosis, and it has antimicrobial activity. Beyond this, at present the scientific reports about the effect of tree tomato fruit in human health are very limited. The authors found no specific scientific studies about this topic.

\section{Physalis peruviana $L$}

\subsection{Botanical aspects}

P. peruviana is commonly known as uchuva in Colombia, uvilla in Ecuador, aguaymanto in Perú, topotopo in Venezuela or goldenberry and cape gooseberry in English-speaking countries [16]. It is an exotic fruit that belongs to the family Solanaceae and genus Physalis, with a characteristic tomato-like flavour and appearance (Fig. 1C), but with a taste (sweet and sour) much richer than this [15]. This fruit is native to the Andes, having transcended the history of periods pre-Incan and Incan $[16,72]$. Different chromosome numbers may exist among distinct genotypes, thus, it has been reported $2 n=24$ for wild ecotypes, $2 n=32$ for the ecotype grown in Colombia or $2 n=48$ for the ecotype cultivated in Kenya [73, 74]. It has remained intact and without apparent changes in the structure of their germplasm, having been described more than 80 wild species and many cultivars of different regions and countries. These varieties differ from one another in size, color and fruit taste, flower shape, plant height and size [16, 75]. In Ecuador, the most produced varieties are "Kenian" and "Lojan", both with orange-yellow berries [76]. Although the collections held in genebanks have been partially evaluated for morphological and agronomic traits [74, 77-79], genetic diversity at the molecular level has been little studied [74, 80].

The plants are perennials in subtropical regions and are herbaceous, upright semi-shrubs that can grow to 0.6 to $0.9 \mathrm{~m}$ and, in some cases, may grow up to $1.8 \mathrm{~m}$. The flowers are yellow with purple blotches and bell-shaped, and can be easily pollinated by insects, wind and through auto-pollination. The fruits generally weigh between 4 to $5 \mathrm{~g}$ and have a diameter from 1.25 to $2.50 \mathrm{~cm}$. They are covered throughout their development and ripening by an accrescent calyx that hangs downwards like a lantern, protecting them against insects, birds, diseases and adverse climatic conditions. Furthermore, this structure represents a major source of carbohydrates during the first 20 days of growth and fruit development. The berries have a brilliant yellow peel and ovoid shape and, contain about 100 to 200 small seeds (Fig. 1C) [16, 81-85].

\subsection{Agronomic aspects}

Cape gooseberries are commercially produced in Australia, Colombia, China, Ecuador, Egypt, Great Britain, Hawaii, India, Kenya, Malaysia, New Zealand, South Africa, Zimbabwe [16, 81, 82, 86, 87]. The crop was introduced to South Africa by the Spaniards and from there it spread to different countries of the tropic and sub-tropics [16]. 
Currently, the major producers are Colombia and South Africa, however, is a minor crop [16, 75, 81, 88]. In Ecuador, P. peruviana is produced in the provinces of Azuay, Carchi, Cotopaxi, Imbabura and Pichincha, counting over 200 hectares in 2011 [89]. Despite its potential, in most countries $P$. peruviana is a backyard plant, nevertheless in some international markets such as Europe, the fruits have recently reached very high prices [90]. They are usually consumed as fresh fruit, however, they can also be served in salads, cooked dishes, desserts, jams, natural snacks, and canned fruit $[75,81]$.

It is a crop with high potential able to grow in a wide range of altitudes (sea level to $3300 \mathrm{~m}$ ) and tolerate low temperatures, growing at an optimum temperature of $18^{\circ} \mathrm{C}$. Thus, their growth and development are affected by very high and very low temperatures, suffering irreparable damage below $0^{\circ} \mathrm{C}$. The plants require high luminescence and wind protection and it is important to provide enough water during the early growth. $P$. peruviana grows in poor soils, but well-drained and has low fertilization requirements. The plants thrive best in slightly acidic soils, although tolerate $\mathrm{pH}$ values between 5.5 to 7.3 with a good organic content and a rainfall between 1000 to $2000 \mathrm{~mm}$. They do not tolerate clay soils because they have superficial roots $[15,16,82]$. P. peruviana yield may be hampered by several fungal and bacterial diseases, viruses, beetles, caterpillars, whiteflies or nematodes that cause different symptoms as damping-off, necrosis or wilt [91]. The crop requires approximately 9 months for the first harvest, having a production time ranging from 9 to 11 months after the first harvest, since thereafter productivity and fruit quality are reduced [16]. A single plant can yield up to 300 fruits and 20 to 33 tons/hectare, however in Ecuador due to different factors it is often reduced about 5 to 7 tons/hectare. The country has about 24.500 hectares with high potentiality for crop planting in the provinces of Imbabura, Pichincha, Bolívar, Loja and Tungurahua (Fig. 2C) [89]. The shelf life of the fruits with calyx is 1 month, whereas without calyx is 4 to 5 days [16]. Fruits are longlasting when stored in a sealed container and kept in a dry atmosphere for several months and they also freeze well [81].

\subsection{Nutrients}

Cape gooseberry fruit is highly valued for its flavor, texture, color, and nutrients. The fruits are a good source of provitamin A, minerals, fatty acids, vitamin $\mathrm{C}$ and vitamin B-complex, such as thiamine, niacin and vitamin B12 (Table 5). The fruits contain approximately $15 \%$ of soluble solid, with fructose as the main sugar, which coupled with the high values of fiber regulate blood glucose levels and control calorie intake. The fatty acid profile of Physalis has presented a high concentration of fatty acids with beneficial health effects, such as linoleic acid (72.42\%). It is noteworthy that linoleic acid-rich diets have been associated as a factor to prevent cardiovascular diseases, atherosclerosis and hypertension. Moreover, saturated fatty acids have represented $12.87 \%$ of total fatty acids, with the palmitic acid as the main acid, while stearic acid content represented about of $2.57 \%$ [82].

\subsection{Phytochemistry}

The main bioactive phytochemicals identified in cape gooseberry have been fundamentally withanolides, with withanolides and physalins as the most frequently groups identified. Carotenoids are another of major compounds identified in cape gooseberry fruits, while flavonoids have also been identified, but as minor constituents (Table 6) [82]. Withanolides are a group of steroidal lactones which have been isolated from the genera Acnistus, Datura, Jaborosa, Lycium, Physalis and Withania of the family Solanaceae [82, 92], which consist of a steroid backbone bound to a lactone or one of its derivatives produced via oxidation of steroids. This class of steroidal lactones involves an ergostane-type framework which C-22 and C-26 are appropriately oxidized to form a (delta)-lactone ring. Withanolides group is subdivided into nine groups: withanolides, withaphysalins, physalins, nicandrenones, jaborols, ixocarpalactones, perulactones, acnistins and miscellaneous withasteroids. In Cape gooseberry approximately 20 types of withasteroids have been identified (Table 6) [92].

\subsection{Health benefits}

In folk medicine cape gooseberry is used for treating diseases such as malaria, asthma, hepatitis, dermatitis, diuretic and rheumatism [82]. Other medicinal properties have been attributed to cape gooseberry, including antiasthmatic, 
Table 5

Nutrient composition of cape gooseberry (Physalis peruviana L.) [82]

\begin{tabular}{|c|c|c|}
\hline Type & Nutrient & Values \\
\hline \multirow[t]{6}{*}{ Proximates } & water $(\mathrm{g} / 100 \mathrm{~g})$ & 85.4 \\
\hline & energy (kcal/100 g) & 53 \\
\hline & protein $(\mathrm{g} / 100 \mathrm{~g})$ & 1.9 \\
\hline & Carbohydrates $(\mathrm{g} / 100 \mathrm{~g})$ & 11.2 \\
\hline & total lipid $(\mathrm{g} / 100 \mathrm{~g})$ & 0.70 \\
\hline & dietary fiber (g/100 g) & 4.9 \\
\hline \multirow[t]{4}{*}{ Minerals } & calcium (mg/100 g) & 9.0 \\
\hline & iron $(\mathrm{mg} / 100 \mathrm{~g})$ & 1.0 \\
\hline & magnesium (mg/100 g) & 22.3 \\
\hline & phosphorus (mg/100 g) & 40.0 \\
\hline \multirow[t]{5}{*}{ Vitamins } & vitamin C (mg/100 g) & 11.0 \\
\hline & vitamin A (I.U) & 720 \\
\hline & thiamine $(\mathrm{mg} / 100 \mathrm{~g})$ & 0.11 \\
\hline & riboflavin (mg/100 g) & 0.040 \\
\hline & $\operatorname{niacin}(\mathrm{mg} / 100 \mathrm{~g})$ & 1.0 \\
\hline \multirow[t]{12}{*}{ fatty acids } & palmitic acid (\% w/w) & 9.38 \\
\hline & palmitoleic acid (\% w/w) & 0.71 \\
\hline & stearic acid $(\% \mathrm{w} / \mathrm{w})$ & 2.67 \\
\hline & oleic acid $(\% \mathrm{w} / \mathrm{w})$ & 10.03 \\
\hline & linoleic acid (\% w/w) & 72.42 \\
\hline & $\alpha$-linoleic acid (\% w/w) & 0.32 \\
\hline & $\operatorname{arachidic} \operatorname{acid}(\% \mathrm{w} / \mathrm{w})$ & 1.36 \\
\hline & behenic acid (\% w/w) & 0.26 \\
\hline & lignoceric acid (\% w/w) & 0.24 \\
\hline & Saturated $(\% \mathrm{w} / \mathrm{w})$ & 12.87 \\
\hline & Monounsaturated $(\% \mathrm{w} / \mathrm{w})$ & 10.71 \\
\hline & Polyunsaturated (\% w/w) & 73.78 \\
\hline
\end{tabular}

antiseptic, and strengthener for the optic nerve, treatment of throat affections and elimination of intestinal parasites, amoebas as well as albumin from kidneys. It has an anti-ulcer activity and it is effective in reducing cholesterol level. Moreover, $P$. peruviana is a medicinal plant widely used in folk medicine as an anticancer, antimycobacterial, antipyretic, and immunomodulatory and also used in the treatment of diseases such as malaria, asthma, hepatitis, dermatitis, and rheumatism [82].

$P$. peruviana has been reported as a natural source of important bioactive compounds such as withanolides and phenolics, which have been associated with a strong oxidant property and prevent peroxidative damage to liver microsomes and hepatocytes [92]. It has been demonstrated that different leaves extracts from P. peruviana showed antihepatotoxic activities against CCl4-induced hepatotoxicity [93].

Moreover, it has also been reported that the ethanolic extract of $P$. peruviana (EEPP) was able to inhibit growth and induces apoptotic death of human Hep G2 cells in culture, proving the potent anti-hepatoma activity and the effect on apoptosis of EEPP. A detailed study to define the molecular mechanism of EEPP-induced apoptosis in Hep G2 cells was recently published [94, 95]. These results could be important as an indication of the potentially nutraceutical and economical utility of cape gooseberry as a new source of bioactive phytochemicals and functional foods. 
Table 6

Phytochemical composition reported in Cape gooseberry (Physalis peruviana L.) [82]

\begin{tabular}{|c|c|c|}
\hline Class & Goup & Compound \\
\hline \multirow[t]{25}{*}{ Withanolides } & Withanolides & withanolide E \\
\hline & & $4 \beta$-hydroxywithanolide $\mathrm{E}$ \\
\hline & & 28-hydroxywithanolide E \\
\hline & & $(20 \mathrm{R}, 22 \mathrm{R})-5 \alpha, 6 \beta, 14 \alpha, 20$ \\
\hline & & 27-pentahydroxy-1-oxowith-24-enolide \\
\hline & & $(20 \mathrm{~S}, 22 \mathrm{R})-5 \beta, 6 \beta$-ероху- $4 \beta, 14 \beta$ \\
\hline & & $15 \alpha$ - hihydroxy-1-oxowith-2,24-dienolide \\
\hline & & phyperunolide A \\
\hline & & phyperunolide B \\
\hline & & phyperunolide $\mathrm{C}$ \\
\hline & & phyperunolide D \\
\hline & & phyperunolide E \\
\hline & & Phyperunolide F \\
\hline & & withanolid S \\
\hline & & withanolid C \\
\hline & & withaperuvin \\
\hline & & physalolactone \\
\hline & & withaphysanolid \\
\hline & & physalactona \\
\hline & & withaperuvin D \\
\hline & & loliolid \\
\hline & Physalins & Physalins A, \\
\hline & & Physalins B \\
\hline & & Physalins D \\
\hline & & Physalins F \\
\hline \multirow[t]{2}{*}{ Flavonoids } & Flavonol & kaempferol 3- $O$-rutinoside \\
\hline & & quercetin 3,4',7-trimethyl ether \\
\hline \multirow[t]{4}{*}{ Carotenoids } & Carotenes & $\alpha$-tocopherol \\
\hline & & $\beta$-tocopherol \\
\hline & & $\gamma$-tocopherol \\
\hline & & $\delta$-tocopherol \\
\hline
\end{tabular}

\section{Conclusions}

The phytochemistry and health benefit uses of two important berries and an aggregate fruit commonly known as a berry, all native to the Andean region, have been reviewed. These plants possess a rich and diversified composition of bioactive compounds as well as health-promoting properties. Nevertheless, studies in vivo and in vitro related to their biological activities are still limited. Although future research is needed to understand their potential in regard to their use as supplements or as functional foods, the studies reviewed demonstrate the health potential of berries from Ecuador; thus, greater attention should be given to native fruits from this region.

Ecuador is being revalued in recent years due to a number of causes such as its great biodiversity and the improved stability (political, economic and social). This together with the increasing demand of natural medicinal products and new bioactive compounds in the last decades is opening a new range of opportunities including new sources of funding for investigations and new research lines. Governmental institutions as the National Institute of Agricultural Research (INIAP), universities and private businesses are boosting the research and trying to highlight the richness and potentialities of the country. So, an increasing number of researches and programmes are approaching the 
conservation, restoration and dissemination of ancestral knowledge, many of them addressing traditional medicine (plants and uses), the search of new bioactive compounds or new applications. Therefore, great potentialities are making their way and awakening new desires and endeavours, leading to enrich society with new bioactive principles, properties and applications and also allow the conservation of traditional practices and Ecuadorian plant species.

\section{Acknowledgments}

The authors are indebted to Dr. Uvaldo Recino for extensively editing the manuscript and the Ministerio de Agricultura, Ganadería, Acuacultura y Pesca (MAGAP, Ecuador), for their collaboration providing the agroeconomic zoning maps of the Andean crops studied. This work has been partially funded by Universidad Nacional de Chimborazo. The authors have no conflict of interest to declare.

\section{References}

[1] Roy-Chaughury R. Herbal Medicine for Human Health. World Health Organization, Regional Office for South-East Asia; 1992.

[2] Tene V, Malagón O, Finzi PV, Vidari G, Armijos C, Zaragoza T. An ethnobotanical survey of medicinal plants used in Loja and ZamoraChinchipe, Ecuador. J Ethnopharmacol. 2007;111:63-81.

[3] Jorgensen PM, León-Yánez S. Catálogo de las plantas vasculares del Ecuador. Monogr Syst Bot from Missouri Bot Gard. 1999;75: $1-1181$.

[4] Williams J, Read C, Norton A, Dovers S, Burgman M, Proctor W, Anderson H. Biodiversity, Australia state of the environment report 2001 (Theme report). Canberra, ACT: CSIRO 2001.

[5] United Nations Environment Programme and Worls Conservation Monitoring Centre: Biodiversity A-Z. http://www.biodiversityaz.org/about

[6] Mittermeier RA, Myers N, Mittermeier CG, Robles Gil P. Hotspots: Earth's biologically richest and most endangered terrestrial ecoregions. CEMEX, SA, Agrupación Sierra Madre, SC 1999.

[7] Myers N, Mittermeier RA, Mittermeier CG, Da Fonseca GA, Kent J. Biodiversity hotspots for conservation priorities. Nature. 2000; 403:853-8.

[8] De la Torre L, Calvo-Irabién LM, Salazar C, Balslev H, Borchsenius F. Contrasting palm species and use diversity in the Yucatan Peninsula and the Ecuadorian Amazon. Biodivers Conserv. 2009;18:2837-53.

[9] Naranjo P, Escaleras R. La Medicina Tradicional en el Ecuador. Quito: Corporación Editora Nacional; 1995.

[10] De la Torre L, Cerón CE, Balslev H, Borchsenius F. A Biodiversity Informatics Approach to Ethnobotany: Meta-analysis of Plant Use Patterns in Ecuador 2012;17.

[11] Zhao Y. Berry Fruit, Value-Added Products for Health promotion. New York: CRC Press; 2007.

[12] Schreckinger ME, Lotton J, Lila MA, Mejia EG. Berries from South America: A Comprehensive Review on Chemistry, Health Potential, and Commercialization. J Med Food. 2010;13:233-46.

[13] Zafra-Stone S, Yasmin T, Bagchi T, Chatterjee A, Vinson JA, Bagchi D. Berry anthocyanins as novel antioxidants in human health and disease prevention. Mol Nutr Food Res. 2007;51:675-83.

[14] Juranic Z, Zixack Z. Biological activities of berries: From antioxidant capacity to anti-cancer effects. BioFactors. 2005;23:207-11.

[15] Ramadan MF, Mörsel JT. Impact of enzymatic treatment on chemical composition, physicochemical properties and radical scavenging activity of goldenberry (Physalis peruviana L.) juice. J Sci Food Agric. 2007;87:452-60.

[16] Puente LA, Pinto-Muñoz CA, Castro ES, Cortés M. Physalis peruviana Linnaeus, the multiple properties of a highly functional fruit: A review. Food Res Int. 2011;44:1733-40.

[17] Hassanien MFR. Physalis peruviana : A Rich Source of Bioactive Phytochemicals for Functional Foods and Pharmaceuticals. Food Rev Int. 2011;27:259-73.

[18] Vasco C, Avila J, Ruales J, Svanberg U, Kamal-Eldin A. Physical and chemical characteristics of golden-yellow and purple-red varieties of tamarillo fruit (Solanum betaceum Cav.). Int J Food Sci Nutr. 2009;60 Suppl 7:278-88.

[19] Acosta-Quezada PG, Raigón MD, Riofrío-Cuenca T, et al. Diversity for chemical composition in a collection of different varietal types of tree tomato (Solanum betaceum Cav.), an Andean exotic fruit. Food Chem. 2015;169:327-35.

[20] Lim TK. Edible Medicinal And Non-Medicinal Plants. 2013;6:326-32.

[21] Morales AL, Albarracin D, Rodriguez J, Duque C, Riaño LE, Espitia J. Volatile Constituents from Andes Berry (Rubus glaucus Benth) 1996;1:585-7.

[22] Mertz C, Brat P, Caris-Veyrat C, Gunata Z. Characterization and thermal lability of carotenoids and vitamin C of tamarillo fruit (Solanum betaceum Cav.). Food Chem. 2010;119:653-9. 
[23] Garzon G a, Riedl KM, Schwartz SJ. Determination of anthocyanins, total phenolic content, and antioxidant activity in Andes Berry (Rubus glaucus Benth). J Food Sci. 2009;74:C227-32.

[24] Ballington JR, Luteyn MM, Thompson K, Romoleroux K, Castillo R. Rubus and Vacciniaceous germplasm resources in the Andes of Ecuador. Plant Genet Resour Newsl. 1993;93:9-15.

[25] Jennings DL. The blackberries of South America—an unexplored reservoir of germplasm. Fruit Var J. 1978;32:61-3.

[26] Garridos P. Evaluación de la diversidad geneética de la mora cultivada (Rubus glaucus Benth) y especies emparentadas en zona productivas del Ecuador mediante marcadores moleculares RAPDs, ISSRs, AFLPs. Escuela Politécnica del Ejército, 2009.

[27] Moore J, Janick J. Advanced in fruit breeding. First. Indiana: Purde University Press; 1993.

[28] De la Cadena J, Orellana A. El cultivo de la mora, Manual del Capacitador. Quito: Unidad de Capacitación de Fruticultura. Instituto Nacional de Capacitación Campesina. Ministerio de Agricultura y Ganadería.; 1984.

[29] Romoleroux K. Flora of Ecuador. First. Estocolm: University of Goteborg; 1996.

[30] Meret M, Brat P, Mertz C, Lebrun M, Günata Z. Contribution to aroma potential of Andean blackberry (Rubus glaucus Benth.). Food Res Int. 2011;44:54-60.

[31] Estupiñan DC, Schwartz SJ, Garzón G a. Antioxidant activity, total phenolics content, anthocyanin, and color stability of isotonic model beverages colored with Andes berry (Rubus glaucus Benth) anthocyanin powder. J Food Sci. 2011;76:S26-34.

[32] Jiménez D, Cock J, Satizábal HF, et al. Analysis of Andean blackberry (Rubus glaucus) production models obtained by means of artificial neural networks exploiting information collected by small-scale growers in Colombia and publicly available meteorological data. Comput Electron Agric. 2009;69:198-208.

[33] Mejía-Bonilla PR. Caracterización morfoagronómica de genotipos de mora (Rubus glaucus Benth) en la granja experimental TumbacoINIAP. Escuela Politécnica del Ejército, 2011.

[34] Bucheli VH, González AS, Aguilar DR, et al. Del cultivo de mora (Rubus glaucus) resumen ejecutivo. Quito (Ecuador): 2014.

[35] III Censo Nacional Agropecuario. Quito: 2000.

[36] Osorio C, Hurtado N, Dawid C, et al. Chemical characterisation of anthocyanins in tamarillo (Solanum betaceum) and Andes berry (Rubus glaucus Benth.) fruits. Food Chem. 2012;132:1915-21.

[37] Martínez A, Beltrán O, Velastegui G, et al. Manual de cultivo de la mora de castilla (Rubus glaucus B.). First. Ambato: INIAP-UTA; 2007.

[38] García M, García H. Manejo cosecha y postcosecha de mora, lulo y tomate de árbol. Bogotá (Colombia): CORPOICA; 2001.

[39] US Department of Agriculture, Agriculture Research Service. USDA national nutrient for standard references, release 27. Fruits and fruit juices; 2010, pp. 785-7. Available at: http://www.ars.usda.gov/Services/docs.htm?docid=8964. Accessed on December 9, 2014.

[40] Jungmin J, Dossett M, Finn CE. Rubus fruit phenolic research: The good, the bad, and the confusing. Food Chem. 2012;130:785-86.

[41] Mertz C, Cheynier V, Gunata Z, Brat P. Analysis of phenolic compounds in two blackberry species (Rubus glaucus and Rubus adenotrichus) by highperformance liquid chromatography with diode array detection and electrospray ion trap mass spectrometry. J Agric Food Chem. 2007;55:8616-24.

[42] Garzon GA, Riedi KM, Schwartz SJ. Determination of anthocyanins, total phenolic content, and antioxidant activity in Andes berry (Rubus glaucus Benth). J Food Sci. 2009;74:C227-32.

[43] Vasco C, Riihinen K, Kemal-Eldin A. Phenolic compounds in Rosaceae fruits from Ecuador. J Agric Food Chem. 2009;57:1204-12.

[44] Unpublished data. Personal reference. Interviews in indigenous communities of Riobamba, Ecuador. December, 2014.

[45] Fang J. Bioavailability of anthocyanins. Drug Metab Rev. 2014;46:508-20.

[46] mes BN. Shigenaga MK, Hagen TM. Oxidants, antioxidants, and the degenerative diseases of aging. Proc Nat Acad Sci. 1993;90:7915-22.

[47] Tulipani S, Romandini S, Busco F, Bompadre S, Mezzetti B, Battino M. Ascorbate, not urate, modulates the plasma antioxidant capacity after strawberry intake. Food Chem. 2009;117:181-8.

[48] Cao G, Russell RM, Lischner N, Prior RL. Serum antioxidant capacity is increased by consumption of strawberries, spinach, red wine or vitamin C in elderly women. J Nutr. 1998;128:2383-90.

[49] Romandini S, Mazzoni L, Giampieri F, Tulipani S, Gasparrini M, Forbes-Hernandez TY, Locorotondo N, D’Alessandro M, Mezzetti B, Bompadre S, Alvarez-Suarez JM. Effects of an acute strawberry (Fragaria $\times$ ananassa) consumption on the plasma antioxidant status of healthy subjects. J Berry Res. 2013;3:169-79.

[50] Tulipani S, Alvarez-Suarez JM, Busco F, Bompadre S, Mezzetti B, Battino M. Strawberries improve plasma antioxidant status and erythrocyte resistance to oxidative hemolysis. Food Chem. 2011;128:180-6.

[51] Kaume L, Howard LR, Devareddy L. The blackberry fruit: A review on its composition and chemistry, metabolism and bioavailability, and health benefits. J Agric Food Chem. 2012;13:60:5716-27.

[52] Rice-Evans CA, Miller NJ, Paganga G. Structure-antioxidant activity relationships of flavonoids and phenolic acids. Free Radical Biol Med. 1996;20:933-56.

[53] Butler D. UN targets top killers. Nature. 2011;477:260-1.

[54] Basu A, Rhone M, Lyons TJ. Berries: Emerging impact on cardiovascular health. Nutr Rev. 2010;68:168-77.

[55] Esterbauer H, Schmidt R, Hayn M. Relationships among oxidation of low-density lipoprotein, antioxidant protection, and atherosclerosis. Adv Pharmacol. 1996;38:425-56. 
[56] Chiva-Blanch G, Visioli F. Polyphenols and health: Moving beyond antioxidants. J Berry Res. 2012;2:63-71.

[57] Giusti MM, Jing P. Natural pigments of berries: Functionality and application. In Berry Fruit. Value-Added Products for Health Promotion, 1st ed.; Zhao, Y., Ed.; CRC: Boca Raton, FL, 2007;1:105-46.

[58] Garcia-Alonso M, Minihane AM, Rimbach G, Rivas-Gonzalo JC, de Pascual-Teresa S. Red wine anthocyanins are rapidly absorbed in humans and affect monocyte chemoattractant protein 1 levels and antioxidant capacity of plasma. J Nutr Biochem. 2009;20:521-29.

[59] Alvarez-Suarez JM, Giampieri F, Tulipani S, et al. One-month strawberry-rich anthocyanin supplementation ameliorates cardiovascular risk, oxidative stress markers and platelet activation in humans. J Nutr Biochem. 2014;25:289-94.

[60] Freedman, J. E.; Parker, C.; Li, L.; Perlman, J. A.; Frei, B.; Ivanov, V.; Deak, L. R.; Iafrati, M. D.; Folts, J. D. Select flavonoids and whole juice from purple grapes inhibit platelet function and enhance nitric oxide release. Circulation. 2001;103:2792-98.

[61] Duthie SJ. Berry phytochemicals, genomic stability and cancer: Evidence for chemoprotection at several stages in the carcinogenic process. Mol Nutr Food Res. 2007;51:665-74.

[62] Tate P, Stanner A, Shields K, Smith S, Larcom L. Blackberry extracts inhibit UV-induced mutagenesis in Salmonella typhimurium TA100. Nutr Res. 2006;26:100-4.

[63] Bucheli VH, González AS, Aguilar DR, et al. DEL CULTIVO DE TOMATE DE ÁRBOL (Solanum betaceum) RESUMEN EJECUTIVO. Quito (Ecuador): 2014.

[64] Acosta-Quzada PG. Caracterización morfológica y molecular de tomate de árbol, Solanum betaceum Cav. (Solanaceae). Universidad Polictécnica de Madrid. Escuela Técnica Superior de Ingenieros Agrónomos, 2011.

[65] Acosta-Quezada PG, Martínez-Laborde JB, Prohens J. Variation among tree tomato (Solanum betaceum Cav.) accessions from different cultivar groups: Implications for conservation of genetic resources and breeding. Genet Resour Crop Evol. 2010;58:943-60.

[66] Acosta-quezada PG, Martínez JB. Morphological and Molecular Diversity in a Collection of the Andean Tree Tomato (Solanum betaceum Cav.) 2011;68:500-1.

[67] Thies E. Promising and Underutilized Species Crops and Breeds. Eschborn (Germany): Deutsche Gesellschaft für Technische Zusammenarbeit (GTZ); 2000.

[68] Tamayo PJ. Tomate de árbol. Princ. enfermedades del tomate árbol, la mora y el lulo en Colomb., vol. 12, Antioquia (Colombia): CORPOICAINCORA; 2001, pp. 6-13.

[69] Mertz C, Gancel AL, Gunata Z. et al. Phenolic compounds, carotenoids and antioxidant activity of three tropical fruits. J Food Comp Analysis. 2009;22:381-7.

[70] Ginter E, Simko V, Panakova V. Antioxidants in health and disease. Bratisl Lek Listy. 2014;115:603-6.

[71] Mabel Ordoñez R, Zampini IC, Rodríguez F, et al. Radical scavenging capacity and antimutagenic properties of purified proteins from Solanum betaceum fruits and Solanum tuberosum tubers. J Agric Food Chem. 2011;59:8655-60.

[72] Popenoe H, King S, León J, Kalinowski L. Goldenberry (cape gooseberry). Lost Crop. Incas Little-known Plants Andes with Promise Worldw. Cultiv., Washington DC: National Research Council National Academy Press; 1990, pp. 241-52.

[73] Nohra C, Rodríguez C, Bueno A. Study of the cytogenetic diversity of Physalis peruviana L.(Solanaceae). Acta Biológica Colomb. 2006;95:132-83.

[74] Simbaqueba J, Sánchez P, Sanchez E, et al. Development and characterization of microsatellite markers for the Cape gooseberry Physalis peruviana. PLoS One. 2011;6:e26719.

[75] Bravo K, Sepulveda-Ortega S, Lara-Guzman O, Navas-Arboleda A a, Osorio E. Influence of cultivar and ripening time on bioactive compounds and antioxidant properties in Cape gooseberry (Physalis peruviana L.). J Sci Food. 2015;95:1562-69.

[76] Beltrén AP. PRODUCCIÓN Y EXPORTACIÓN DE UVILLA (Physalis peruviana L.) AL MERCADO DE ALEMANIA. Universidad Tecnológica Equinoccial, 2009.

[77] Lagos-Burbano TC, Criollo-Escobar H, Ibarra A, Hejeile H. Caracterización morfológica de la colección Nariño de uvilla o uchuva Physalis peruviana L. Fitotec Colomb. 2003;3:1-9.

[78] Ligarreto GA, Lobo M, A. C. Recursos genéticos del género Physalis en Colombia. In: Fischer G, Miranda D, Piedrahita D, J. R, editors. Av. en Cultiv. poscosecha y Export. ń la uchuva (Physalis peruviana L) en Colomb., Bogotá: Unibiblios, Universidad Nacional de Colombia; 2005, pp. 9-27.

[79] Trillos-González O, Cotes-Torres JM, Medina-Cano CI, Lobo Arias M, Navas-Arboleda AA. Caracterización morfológica de cuarenta y seis accesiones de uchuva (Physalis peruviana L.), en Antioquia (Colombia). Rev Bras Frutic 2008;30:708-15.

[80] Muñoz-Florez JE, Morillo-Coronado AC, Morillo-Coronado Y. Random amplified microsatellites (RAMs) in plant genetic diversity studies. Acta Agron. 2008;57:219-26.

[81] Ramadan MF, Mörsel JT. Oil Goldenberry (Physalis peruviana L.). J Agric Food Chem. 2003;51:969-74.

[82] Ramadan MF. Bioactive phytochemicals, nutritional value, and functional properties of cape gooseberry (Physalis peruviana): An overview. Food Res Int. 2011;44:1830-6.

[83] Zapata JL, Sldarriaga A, Londoño M, Díaz C. Manejo del cultivo de la uchuva en Colombia. Antioquía (Colombia): CORPOICA-Programa Regional de Investigación Agrícola; 2002.

[84] Ramadan MF, Mörsel JT. Goldenberry: A novel fruit source of fat soluble bioactives. Inform. 2004;15:130-1. 
[85] McCain R. Goldenberry, passionfruit and white sapote: Potential fruits for cool subtropical areas. In: Janick J, Simon JE, editors. New Crop., New York: Wyley and Sons; 1993, pp. 479-86.

[86] Morton JF. Cape gooseberry. In: Morton JF, editor. Fruits warm Clim., Winterville: NC: Creative Resources Systems Inc.; 1987, pp. 430-4.

[87] Rehm S, Espig G. Fruit. In: Digmund R, Gustav E, editors. Cultiv. plants Top. Subtrop. Cultiv. Econ. value, Util., Weikersheim: Verlag Josef Margraf; 1991, pp. 169-245.

[88] Novoa RH, Bojacá M, Galvis JA, Fischer G. Fruit maturity and calyx drying influence post-harvest behavior of Cape gooseberry (Physalis peruviana L.) stored at $12^{\circ}$ C. Agron Colomb. 2006;24:77-86.

[89] Bucheli VH, González AS, Aguilar DR, et al. DEL CULTIVO DE UVILLA (Physalis peruviana) RESUMEN EJECUTIVO. Quito (Ecuador): MAGAP; 2014.

[90] Rodrigues E, Rockenbach II, Cataneo C, Gonzaga LV, Chaves ES, Fett R. Minerals and essential fatty acids of the exotic fruit Physalis peruviana L. 2009;29:642-5.

[91] Mayorga H, Duque C, Knapp H, Winterhalter P. Hydroxyester disaccharides from fruits of cape gooseberry (Physalis peruviana). Phytochemistry. 2002;59:439-45.

[92] Lan YH, Chang FR, Pan MG et al. New cytotoxic withanolides from Physalis peruviana. Food Chem. 2009;116:462-9.

[93] Arun M, Asha VV. Preliminary studies on antihepatotoxic effect of Physalis peruviana Linn. (Solanaceae) against carbon tetrachloride induced acute liver injury in rats. J Ethnopharmacol. 2007;111:110-14.

[94] Wu SJ, Ng LT, Chen CH, Lin DL, Wang SS, Lin CC. Antihepatoma activity of Physalis angulata and Physalis peruviana extracts and their effects on apoptosis in human Hep G2 cells. Life Sci. 2007;4:2061-73.

[95] Wu SJ, Ng LT, Lin DL, Wang SS, Lin CC. Physalis peruviana extract induces apoptosis in human Hep G2 cells through CD95/CD95L system and the mitochondrial signaling transduction pathway. Cancer Lett. 2004;215:199-208. 